REVIEW

\title{
Gastric Mucosal Injury: Microcirculation and Helicobacter Pylori
}

\author{
Hidekazu Suzuki, Soichiro Miura, Masayuki Suzuki', Soichiro Terada², \\ Masahiko Nakamura and Masaharu Tsuchiya
}

\begin{abstract}
Department of Internal Medicine, School of Medicine, Keio University, 'Department of Internal Medicine, Tokyo Metropolitan Hiroo General Hospital, Tokyo and ${ }^{2}$ Department of Internal Medicine, Shizuoka Red Cross Hospital, Shizuoka, Japan
\end{abstract}

(Received for publication on August 17, 1993)

\begin{abstract}
The integrity of gastric mucosa is well-balanced by an array of defensive mechanisms which protect the mucosa against external aggressive factors. When excessive stimulation of autonomic nervous system (irritation) is induced, microcirculatory disturbances easily lead to the gastric mucosal damage due to the formation of vasoactive mediators and oxygen radicals. In this review, our discussion has been focused on the co-ordinating function of the autonomic nervous system as well as the microcirculation as an important defense bastion. In this context, Helicobacter pylori represents an important pathogenic factor. In particular, we have discussed the contribution of monochloramine, and active oxidant, which is formed by neutrophils in the presence of ammonia derived from $\mathrm{H}$. pylori to the gastric mucosal injury. Microcirculatory disturbances may be also involved in the pathogenesis of $\mathrm{H}$. pylori-induced mucosal injury. On the basis of these considerations, we should not depend solely on the use of anti-acid secretory drugs for the treatment of gastric mucosal injury, but also should be aware of beneficial effect of mucosal protective drugs which may act on microcirculation and the autonomic nervous system. (Keio I Med 43 (1): 1-8, March 1994)
\end{abstract}

Key words: autonomic nervous system, irritation, oxygen radicals, gastritis, gastric ulcer

\section{Introduction}

In 1937, Hans Selye pointed out that stress can affect not only the adrenal glands, thymus, and lymphatic system but also the gastric mucosa. ${ }^{1}$ It should be noted, however, that the was not the first person who found gastric mucosal lesions as a result of stress. His teacher. Dr James Reilly described in early 1930's the concept of an irritation syndrome characterized by nonspecific hemorrhagic lesions in multiple organs due to excessive stimulation of autonomic nervous system. ${ }^{2}$

A variety of factors is known to contribute to the pathogenesis of the gastric mucosal lesions. As might be anticipated, aggressive factors from the luminal side are important, especially the role of acid, a feature referred to as hydrogen back diffusion theory. ${ }^{3}$ Davenport postulated in 1964 that when acid penetrates the mucosal barrier into lamina propria, mast cells are activated and release histamine. Acid and histamine induce micro- vascular, neural and epithelial damage in the gastric mucosa. The precise contribution of microcirculatory and autonomic nervous system factors remains, however, largely undoccumented. ${ }^{3}$ In addition, it has recently been reported that a particular strain of bacteria, Helicobacter pylori ( $\mathrm{H}$. pylori), was one of pathogenic factors of gastric mucosal injury. ${ }^{4}$ In the present review, we have summarized the pathogenesis of gastric mucosal injury from a microcirculatory viewpoint (Fig 1).

\section{Morphological Findings of Gastric Mucosa}

Abundant vascular networks are revealed in the lamina propria of the gastric mucosa by scanning electron microscopic observations. These capillary sized vessels are shown to reach the surface of the mucosa. Collecting venules which drain blood from the capillaries, descend directly into the submucosa. Under higher magnification of gastric mucosal surface, fine nerve fibers can be detected

鈴木秀和, 三浦総一郎, 鈴木雅之, 寺田総一郎, 中村正彦, 土屋雅春

Reprint requests to: Dr Masaharu Tsuchiya, Department of Internal Medicine, School of Medicine, Keio University, 35 Shinanomachi, Shinjukuku, Tokyo 160, Japan 


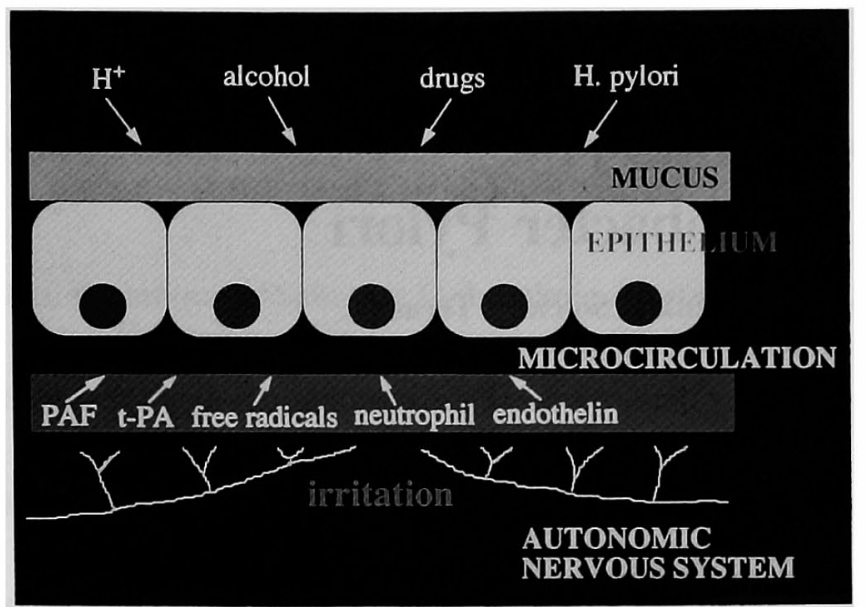

Fig 1 Summary of a major factor in the pathogenesis of gastric mucosal injury. The three important factors for gastric mucosal homeostasis are autonomic nervous factor, microcirculatory factor and mucus factor. Not only do acid, alcohol, drugs and Helicobacter pylori appear to be involved, but the aforementioned three factors could represent aggressive factors during the course of irritation.

along side of the true capillary networks which surround the epithelial cells. The cholinergic innervation of the stomach is made up of an intrinsic and extrinsic set of fibers from the vagal nerve. The vagal input to the enteric nervous system originates in the dorsal motor nucleus of the medulla oblongata. ${ }^{5}$ The vagii at the level of the diaphragm contain an average of 56,138 afferent fibers and only 1736 efferent fibers. ${ }^{6}$ Most of the cholinergic nerves in the gastric mucosa belong to the enteric nerves. The histochemical localization of such cholinergic nerves was demonstrated by acetylcholinesterase (AchE) activity ${ }^{7-9}$ and choline acetyltransferase (ChAc) immunoreactivity. ${ }^{10}$ With this method, cholinergic nerve fibers in the lamina propria were stained a brown color and could be seen to be distributed along the true capillaries up to the surface of mucosa (Fig 2). This relationship suggested a close functional interaction among true capillaries, the autonomic nervous system and epithelial cells. Sympathetic pathways transmit command signals from the central nervous system via spinal nerves terminating in celiac ganglia and function to reduce gastrointestinal blood flow and motility. From these ganglia, the postganglionic adrenergic fibers reach the stomach either as discrete nerves, or as nerves closely associated with vagal nerves or the nerves that accompany the arterial vessels. Nerves fibers showing specific noradrenaline fluorescence are located mainly in the perivascular plexuses of the arterioles and to a lesser extent in the myenteric and submucosal nerve plexuses by the Falck-Hillarp's method and its modification (Fig 3). It has also been reported that adrenergic nerves were located in close contact with arterioles and venules

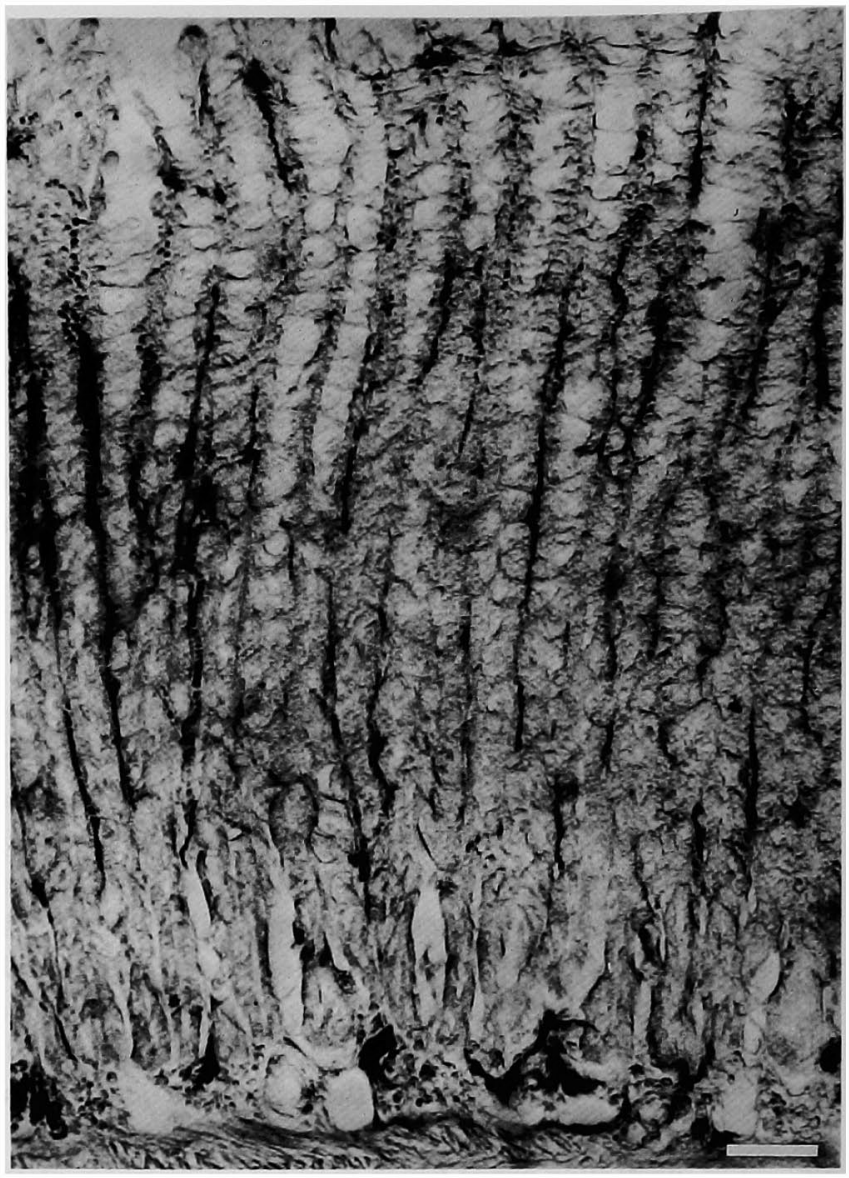

Fig 2 The acetylcholinesterase-positive nerve fibers are recognized aligned linearly between the gastric epithelial cell column. Bar indicates $20 \mu \mathrm{m}$.

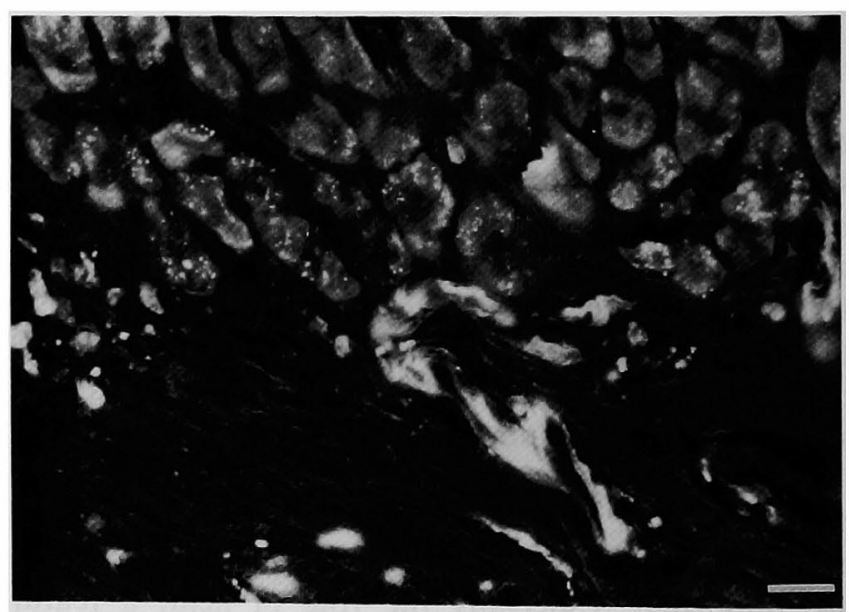

Fig 3 The noradrenaline-specific fluorescence is seen largely surrounding the arteriole and to a lesser degrees in the lamina propria mucosae. Bar indicates $10 \mu \mathrm{m}$.

in the basal portion of mucosa and that adrenergic and cholinergic nerves sometimes coexist in the same Schwann 
cell aligned close to the true capillary. ${ }^{1-13}$ The contraction of the appropriate smooth muscle cells is also shown in pharmacological and histochemical studies to be influenced by dopamine. ${ }^{14}$ Such dopaminergic nerves are identified histochemically as dopamine-betahydroxylase negative and tyrosine hydroxylase positive nerve fibers. On the basis of this criterion, it has been possible to identify many dopaminergic nerves near the arterioles in the muscularis mucosae and propriae in addition to their colocalization with the adrenergic nerves in perivascular plexuses. ${ }^{15}$ Various types of peptidergic nerves are recognized in the stomach. Vasoactive intestinal peptide (VIP), gastrin releasing peptide (GRP), neuropeptide Y (NPY), and calcitonin generelated peptide (CGRP) are especially abundant in the stomach. ${ }^{16}$ While VIP and CGRP act as a vasodilator, GRP and NPY act as a vasoconstrictor in the stomach. It has been reported that VIP increases a gastric mucosal blood flow. ${ }^{17}$ The VIPergic nerves and the GRPimmunoreactive nerves are found to have the same distribution as a cholinergic nerves. ${ }^{18}$ Although GRP was identified as a brain-gut peptide at first and thought to be mainly concerned with the secretion of gastrin from the $G$ cell in the antral region of the stomach, recent histochemical studies have revealed that GRP is principally localized in the muscular layer. ${ }^{19}$ On the other hand, NPY is thought to be one of the typical braingut peptides which coexists with noradrenaline in the adrenergic nerves. ${ }^{20}$ Recently, CGRP has attracted attention in the context of its relationship to the afferent nervous regulation of the gastric circulation, because acute capsaicin treatment was found to suppress the formation of gastric mucosal lesions and capsaicin has been found to have a strong effect on the afferent nervous activity mediated by CGRP. ${ }^{21,22}$

\section{Experimental Model of Irritation-induced Gastric Mucosal Injury}

Male Wistar rats were used for the study of gastric mucosal injury. Experimental gastric mucosal injury was induced by repeated electrical stimuli $(30 \mathrm{~V}, 5 \mathrm{msec}$, $50 \mathrm{~Hz}$ ) on the left arterial wall (Fig 4). Thirty minutes later, apparent gastric hemorrhagic lesions developed in the glandular stomach, and at that time gastric mucosa and regional blood from the gastric vein were taken for the assay of various biochemical parameters. ${ }^{23}$ Endothelin is an endothelium-derived constrictive factor which was found in $1988 .{ }^{24}$ On the other hand, another mediator, endothelium-derived relaxing factor (EDRF), has been identified as nitric oxide (NO) or a closely related molecule synthesized from the guanido group of L-arginine by nitric oxide synthase (NOS). ${ }^{25}$ The concentration of endothelin appeared to be increased in the gastric

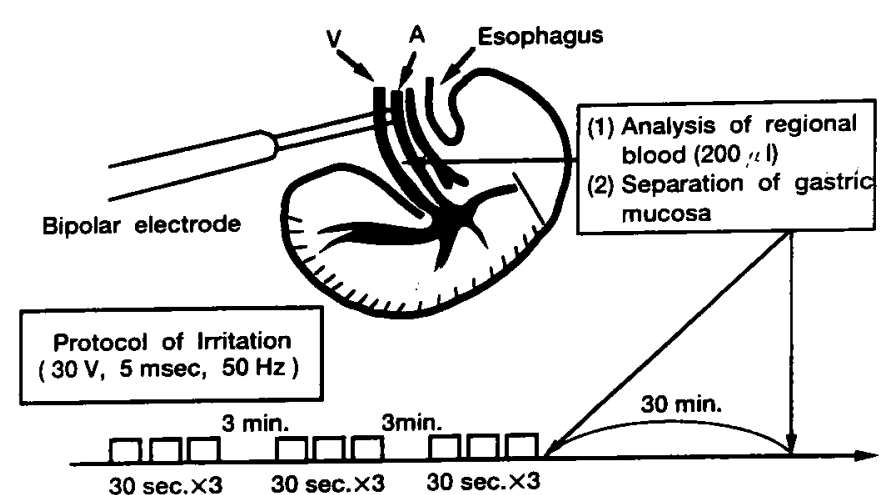

Fig 4 The protocol for experimental gastric mucosal injury induced by repeated electrical stimuli. The small gastric artery in the lesser curvature of fasted Male Wistar rats $(250 \mathrm{~g})$ was exposed in order to apply repeated electrical stimulation (irritation: $30 \mathrm{~V}$, $5 \mathrm{msec}, 50 \mathrm{~Hz}$ ) for $30 \mathrm{sec}$, three times with $10 \mathrm{sec}$ intervals, using a bipolar platinum electrode. This irritation was then repeated three times with $3 \mathrm{~min}$ interval. Prior to and after the irritation, samples of venous blood $(200 \mu \mathrm{l})$ were collected from the gastric vein for analysis of tissue type plasminogen activator (t-PA), plasminogen activator inhibitor (PAI) and chemiluminescence value. The area covered by ulcers and erosions was determined $30 \mathrm{~min}$ after the completion of irritation.

regional blood immediately after the irritation, whereas there was no increase at the systemic level. In contrast, the activity of NOS was significantly decreased after the irritation, suggesting an inbalance of substances which regulate vascular tonus (unpublished observation).

Vasomotor derangements induce fibrinolytic activation and further exacerbate the endothelial cell damage. Subsequent to the irritation, the ratio of prostacyclin $\left(\mathrm{PGI}_{2}\right)$ and thromboxane $\mathrm{A}_{2}\left(\mathrm{TxA}_{2}\right)$ was decreased, a feature which might trigger platelet aggregation. In the gastric mucosa, the content of PAF (plateletactivating factor) and t-PA(tissue-type plasminogen activator) levels were elevated suggesting the development of endothelial damage in gastric mucosa. The t-PA activity ${ }^{26}$ in the regional blood of the stomach was significantly elevated as early as $5 \mathrm{~min}$ after the irritation. Immunohistochemical study using anti-t-PA monoclonal antibody revealed that t-PA was detectable in the endothelial cells of capillaries and collecting venules, suggesting the involvement of endotheliummediated fibrinolytic activity in the irritation-induced ulcer formation. Pretreatment with SOD or allopurinol significantly attenuated the irritation-induced t-PA activation, suggesting that the t-PA activity was modulated by xanthine oxidase-associated superoxide anions. CV-6209, a selective antagonist of PAF, also prevented the activation of t-PA as well as ulcer formation, leading to the concept that PAF may be associated with the local 
fibrinolytic activation which in turn may cause hemorrhagic changes in the gastric mucosal microvasculature. ${ }^{27}$

Inflammatory mediators including PAF induce increased vascular permeability, leukocyte accumulation and enhanced oxygen radical generation in the gastric mucosa. PAF, synthesized by activated endothelial cells, is rapidly and transiently expressed on the cell surface and signals to neutrophilic leukocytes to bind. ${ }^{28} \mathrm{PAF}$ associated with endothelial cells activates neutrophilic leukocytes by binding to a cell surface receptor. Occupation of this receptor by PAF induces upregulation of integrins which mediate the adhesive interaction. ${ }^{28,29}$ Neither a microvascular adherent change of leukocytes nor an increased mucosal activity of myeloperoxidase (MPO) was observed during the earliest period after the completion of the irritation, suggesting that PAF induced integrin upregulation has not been completed in such a short period. Thiry minutes after irritation, there was an increase in myeloperoxidase(MPO) activity in the gastric mucosa, a good indicator of neutrophil accumulation. Luminol-dependent chemiluminescence values from regional neutrophils was also enhanced, suggesting an important role of neutrophil-mediated oxidative stress in the process of gastric mucosal injury. ${ }^{30}$ The contributory role for oxygen radicals has been reported in hemorrhagic shock-induced gastric lesions in the rat. ${ }^{31}$

\section{Helicobacter Pylori and Gastric Mucosal Lesions}

Another important defense factor is the gastric mucus. Gastric mucus covering the mucosa was stained by PAS and gastric mucous secretory cells were clearly stained blue by alcian blue. Ruthenium red block stain was applied to show by electron microscopically the glycocalix of mucin. Not only the surface glycocalix but also secretary granules on the surface mucous cells were recognized as electron dense materials. Surprisingly, some types of bacteria appeared on the surface of mucosa. Such observations had already been made 1940 , Doenges $^{32}$ and Freedberg ${ }^{33}$ who pointed out the presence of Spirochaeta-like organism in human gastric mucosa. However in 1954, Palmer $^{34}$ concluded that there was no evidence of such bacteria from observation on the basis of hematoxylin-eosin stained specimens, and there followed a thirty year silence on this debate. Then in 1983, Warren and Marshall ${ }^{4,35}$ reported that campylobacter-like bacilli could be found in the gastric biopsy specimens. This organism has been referred to as Helicobacter pylori, since in 1989 , Goodwin was able to characterize this bacteria from gene and lipid analysis. ${ }^{36}$ Although this organism in rarely visible after the ordinary hematoxylin-eosin staining, is clearly demonstrated by Wartin-Starry staining. The natural habitat of the bacterium appears to be the gastric mucus layer. ${ }^{37}$ In line with electron microscopical findings, Helicobacter pylori has several flagella. The vast majority of $\mathrm{H}$. pylori organisms are seen in the pit mucus or in the surface mucous layer, close to the epithelial cells (Fig 5). ${ }^{38}$ Ruthenium red may reveal fine filamentous strands extending between organisms and nearby epithelial cells. ${ }^{39}$ Occasionally, organisms appear to congregate at and around intercellular junctions. ${ }^{40} \mathrm{H}$. pylori may also be seen firmly attached to particular cells on the tissue surface by adherence pedestals. ${ }^{41}$ Attached bacteria are particularly striking in cases of epithelial degeneration in the presence of intraepithelial polymorph infiltration. ${ }^{41} \mathrm{H}$.

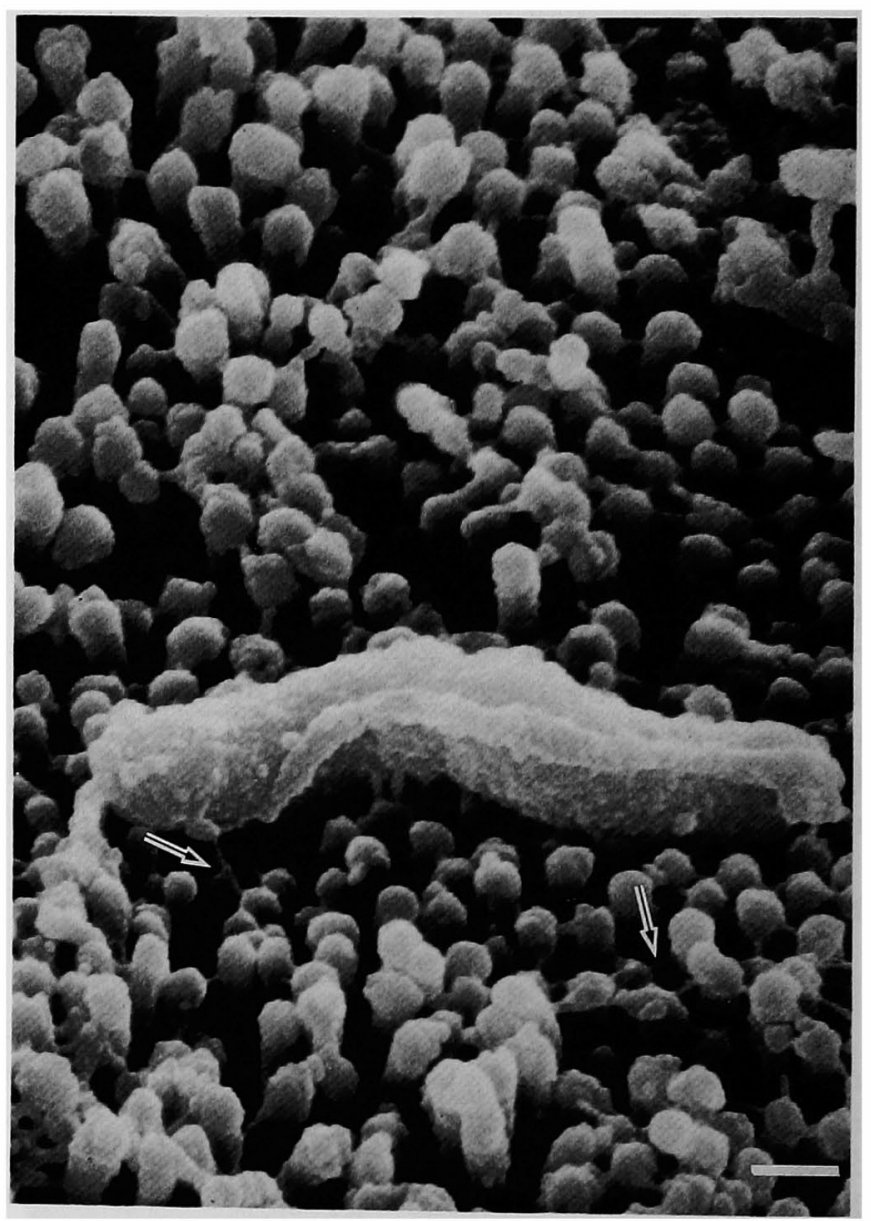

Fig 5 Scanning electron micrograph of the gastric tissues from the patients with Helicobacter pylori ( $H$. pylori)-positive chronic gastritis. There was a long flagella and bacterial body attached with the microvilli of gastric epithelial cells. A glycocalyx (arrows) was observed between the bacterial body and microvilli and between microvilli per se. The microvilli had various forms, such as irregular shapes and thickness. The microvilli attached with the body of $\mathrm{H}$. pylori appeared to have deteriorated and exhibited lower heights compared with the ordered microvilli observed in the upper portions of the figure. Bar indicates $0.2 \mu \mathrm{m}$. 
pylori appears to be a factor in the pathogenesis of both gastritis ${ }^{42-44}$ and gastroduodenal ulcers. ${ }^{44,45} \mathrm{We}$ are now beginning to speculate whether all these $\mathrm{H}$. pylori in the gastric mucosa have a pathogenic role or not. Inasmuch as they could detect in healthy patients, the fact that a high proportion of positive $\mathrm{H}$. pylori infection is encountered among endoscopy patients is difficuly to evaluate. Considerable differences are seen in prevalence between Japan or France and African or South American coun-

Table 1 Differences in Prevalence of Positive Helicobacter Pylori Infection Among Endoscopy Patients

\begin{tabular}{ll}
\hline \hline Japan & $43-50 \%$ \\
France & $48-50 \%$ \\
African Countries & $67-97 \%$ \\
South American Countries & $72-90 \%$ \\
\hline
\end{tabular}

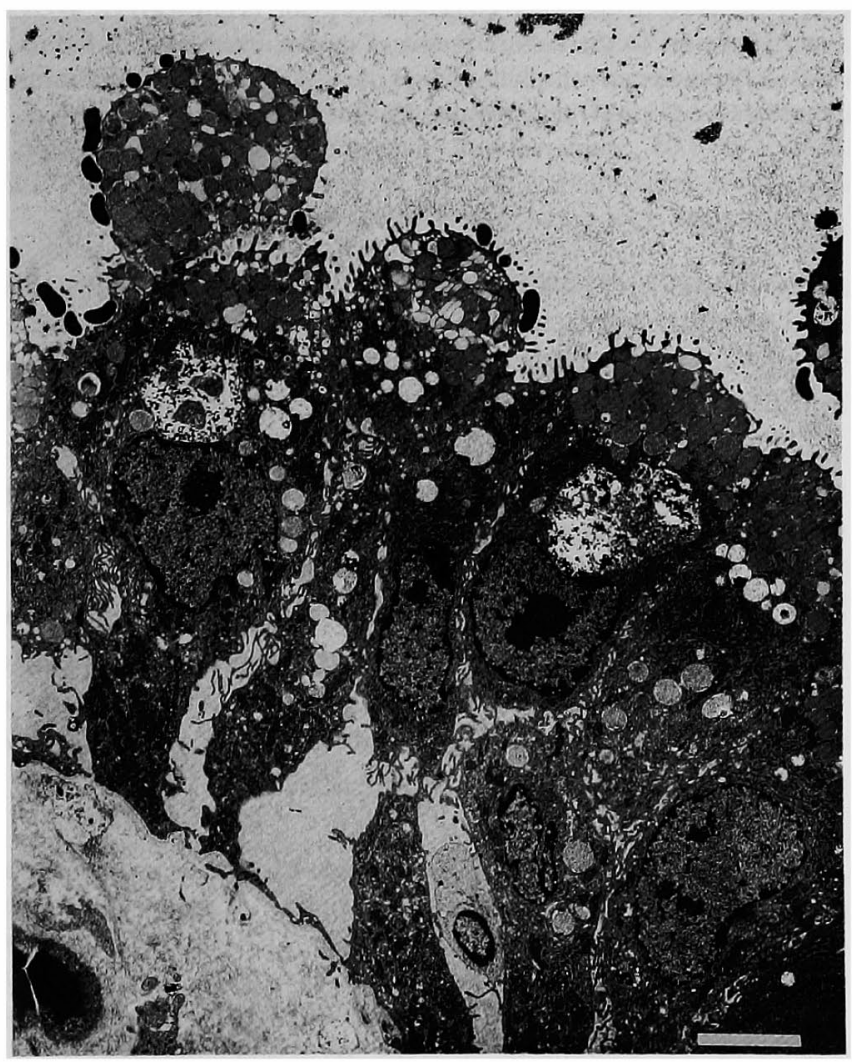

Fig 6 Transmission electron micrograph of the gastric tissues from the patients with Helicobacter pylori (H. pylori)-positive chronic gastritis. $H$. pylori attached to or adjacent to the gastric epithelial cells were observed. As a consequence of the infections with $H$. pylori, vacuolar degeneration and aggregation of mitochondria within the epithelial cells were detected. Also, the junctions of each cell appear to have become looser than those of uninfected epithelial cells. Bar indicates $4 \mu \mathrm{m}$. tries (Table 1). ${ }^{46,47}$ These considerations suggests that the presence of $\mathrm{H}$. pylori may not be directly indicative of a pathogenic role.

Terada, who is one of the present authors, was recently able to demonstrate the distribution of Helicobacter pylori in the gastric mucosa by transmission electron microscopy (Fig 6). ${ }^{48,49}$ According to his findings, at least $66 \%$ of the bacteria was floating in the mucus layer and more than $20 \%$ was facing plasma membranes of gastric epithelial cells. Some $\mathrm{H}$. pylori were adherent to the epithelium forming an "adhesion pedestal". Another interesting statistic was that about $3 \%$ of $\mathbf{H}$. pylori was phagocytized by neutrophils in mucous layer.

$H$. pylori infection produces very high levels of urease activity, an enzyme that is produced within and on the surface of this organism. ${ }^{37,50}$ Urease cleaves urea to produce ammonia, which has a neutralizing or alkalinizing effect on the growth environment. A biopsy urease test relies on its urease activity to diagnose $\mathrm{H}$. pylori infection. $^{51-53} \mathrm{~A}$ number of commercial serological kits are being developed for the diagnosis of $\mathrm{H}$. pylori infection. The best serological tests are all enzyme-liked immunosorbent assays (ELISA), varying in the particular antigens such as urease. ${ }^{54}$ The basis for the urea breath test is the high level of urease produced by the bacterium in vivo. When $\mathrm{H}$. pylori is present in the stomach, swallowed ${ }^{14} \mathrm{C}$ - or ${ }^{13} \mathrm{C}$-labelled urea is broken down and the labelled $\mathrm{CO}_{2}$ produced is rapidly exhaled in the breath. Collected breath samples are analysed for ${ }^{14} \mathrm{CO}_{2}$ in a scintillation counter or for ${ }^{13} \mathrm{CO}_{2}$ by gas isotope ratio mass spectrometry. ${ }^{55-57}$ The $\mathrm{H}$. pylori-infected gastric mucosa is characterized by a profound neutrophil infiltration. It has been reported that the elicitation of regional neutrophils is significantly elevated in patients with $\mathrm{H}$. pylori. When luminol-dependent chemiluminescence values from neutrophil were determined, the combination of Helicobacter pylori and neutrophils strikingly enhanced toxic oxygen radical generation. ${ }^{58}$

By using a newly developed photobiological technique, the interaction among gastric mucosal cells, neutrophils and $\mathrm{H}$. pylori was quantitatively analyzed. ${ }^{58} \mathrm{~A}$ fluorescence dye named BCECF-AM(bis-carboxyethylcarboxyfluorescein acetoxymethyl ester) served as an indicator of cellular injury. This dye easily permeates into the cultured gastric mucosal cells and is hydrolyzed to form BCECF which has fluorescence. When cells are damaged, BCECF fluorescence material is leaked from cells into the culture media (Fig 7-a). After the addition of the neutrophils and $\mathrm{H}$. pylori to the culture media of rabbit gastric mucosal cells, significant leakage of BCECF with deformation of gastric mucosal cells was demonstrated. A scavenger of hydrogen peroxide, catalase, significantly inhibited the BCECF leakage. Taurine and methionine, scavengers of a monochloramine which is a potent cytotoxic oxidant, appeared to 


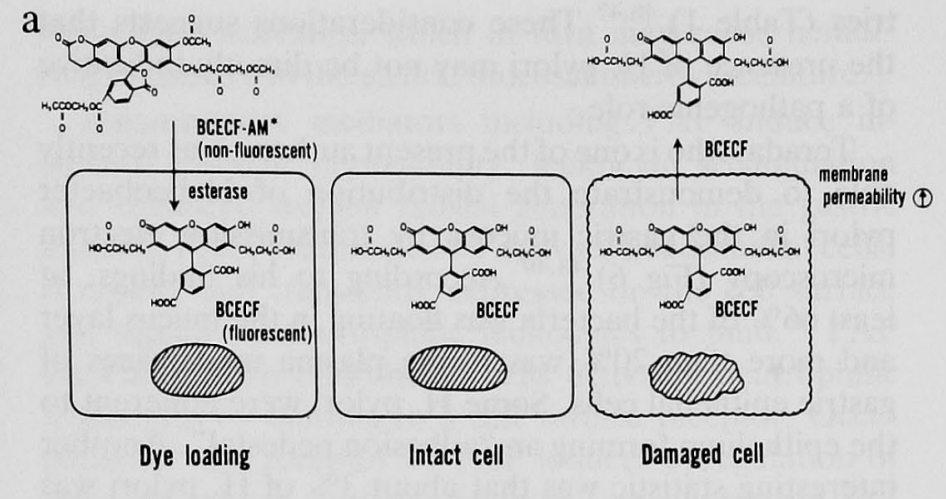

- BCECF-AM : 2;7'bis-(2-carboxyethy)-5(6)carboxyfluorescein acetoxymethyl ester

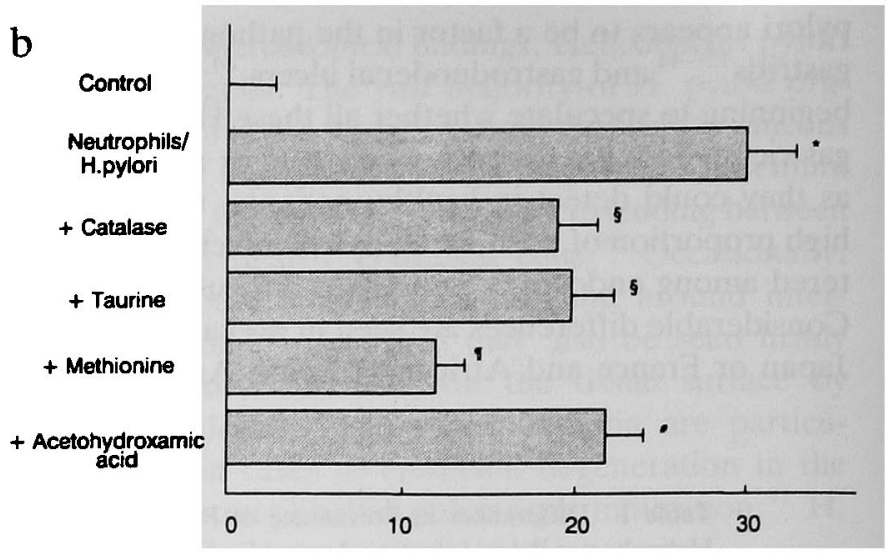

Specific \% Cytotoxicity

Fig 7 a: BCECF-AM (2',7'-bis(2-carboxyethl)-5(6)-carboxyfluorescein acetoxymethyl ester) which is a stable nonfluorescent compound that can diffuse into cells, is hydrolyzed to BCECF $\left(2^{\prime}, 7^{\prime}\right.$-bis(2-carboxyethl)-5(6)-caboxylfluorescein) by intracellular nonspecific esterase and is hereby trapped within the intact cells. BCECF is a fluorescent molecule. When cell damage is induced, BCECF fluorescence is leaked from cells. b: Cytotoxicity of rabbit fetal gastric cells was measured as a specific \% cytotoxicity by the release of the fluorescence dye (BCECF: $\left.2^{\prime}, 7^{\prime}\right)$ bis(2carboxyethl)-5(6)-carboxyfluorescein), which is retained in intact cells. Gastric mucosal cells that were monolayered in a 48-well culture plate were incubated with BCECF-AM (2',7'-bis(2-carboxyethl)-5(6)-carboxyfluorescein acetoxymethyl ester, $5 \mu \mathrm{M})$ for $20 \mathrm{~min}$ at $37^{\circ} \mathrm{C}$. Thereafter, the dye loaded cells were washed with PBS (phosphate buffered solution) once and incubated in 0.5 ml DMEM (Dulbecco's modified Eagle's medium). In the assay, the gastric mucosal cells were incubated with neutrophils $(750,000$ cells/well) and Helicobacter pylori $(\mathrm{H}$. pylori) $(7,500,000$ colony forming unit/well) for 2 hour at $37^{\circ} \mathrm{C}$. The addition of neutrophils and $\mathrm{H}$. pylori to the culture media of gastric mucosal cells led to a significant increase in cytotoxicity. Increased cytotoxicity of gastric mucosal cells in the neutrophils plus $\mathrm{H}$. pylori group was significantly attenuated by the pretreatment of catalase $(2,000 \mathrm{U} / \mathrm{ml})$, taurine $(50 \mathrm{mM})$, methionine $(50 \mathrm{mM})$ and acetohydroxamic acid $(0.5 \mathrm{mg} / \mathrm{ml})$.

${ }^{*} \mathrm{p}<0.01$ compared with value of control for plus $\mathrm{H}$. \& $\mathrm{p}<0.001, \uparrow \mathrm{p}<0.01, \# \mathrm{p}<0.05$, compared with value of neutrophils with $\mathrm{H}$. pylori.

express attenuating effects on cellular injury. Acetohydroxamic acid, an inhibitor of urease also appeared to have an inhibitory effect (Fig 7-b). It has been reported that ammonia which is produced by urease from Helicobactor pylori, could directly damage the

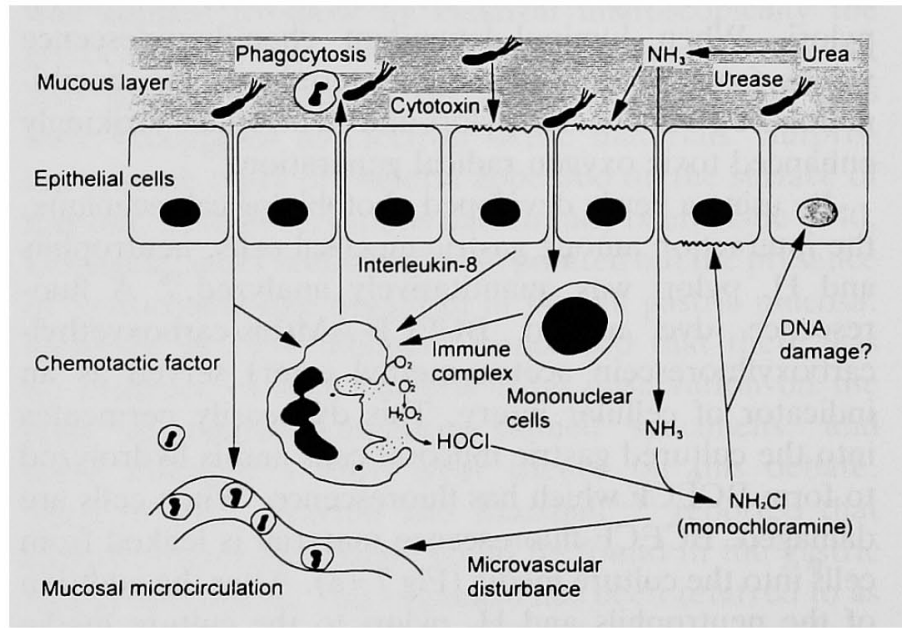

Fig 8 Scheme showing possible mechanisms involved in Helicobacter pylori (H. pylori)-induced gastric mucosal microcirculatory injury. Ureasc-generated ammonia may contribute to the gastric mucosal injury associated with $\mathrm{H}$. pylori. This ammonia-dependent injury may be evoked by activated neutrophils. Participation of ammonia-derived oxidant $\mathrm{NH}_{2} \mathrm{Cl}$ may be an important factor in the formation of $\mathrm{H}$. pylori-induced gastric mucosal injury. gastric mucosa. However, our results imply the important role of neutrophils in this regard since monochloramine which can be formed by neutrophils in the presence of ammonia may enhance gastric mucosal damage (Fig 8).

The so-called "triple therapy" 59 consisting of amoxicillin, bismuth and metronidazol is widely used, but it seems to be aggressive for gastric mucosa. On the other hand, proton, pump inhibitors, such as Omeprazole ${ }^{60}$ or Lansoprazole ${ }^{61}$ are claimed to have potential cytotoxic effect on this organism, but their in vivo effects are not clearly established. It would appear to be more useful to explore the usage of anti-oxidant drugs or agents which modify neutrophil activation.

Acknowledgments: This paper was presented by Masaharu Tsuchiya, $\mathrm{MD}$ at the 5th annual conferrence of Indian Academy of Gastroenterology as a special lecture chaired by Prof BN Tandon, MD, New Delhi, India on February 7, 1993. The authors thank Emeritous Prof BW Zweifach, PhD in University of California San Diego for helpful suggestions and kindful corrections.

\section{References}

1. Selye H, ed: The Story of the Adaptation Syndrome, Told in the Form of Informal, Illustrated Lectures, Montreal, Acta, 1952

2. Reilly J, Rivalier E, Compagnon A, Laplane R: Hémorragies, lésions vasculaires et lymphatiques du tube digestif déterminées par 1 injection périsplanchnique de substances toxiques diverses. Compt Rend Hebd Seances Mem Soc Biol 1934, 116: 24-26 
3. Davenport HW: Fluid produced by the gastric mucosa during damage by acetic and salicylic acids. Gastroenterology 1966, 50: 487-499

4. Warren JR, Marshall B: Unidentified curved bacilli on gastric epithelium in active chronic gastritis [two letters]. Lancet 1983, 1: $1273-1275$

5. Satomi $H$, Yamamoto $T$, Ise $H$, Takatama $H$ : Origins of the parasympathetic preganglionic fibers to the cat intestine as demonstrated by the horseradish peroxidase method. Brain Res 1978 , 151: $571-578$

6. Hoffman $\mathrm{HH}$, Schnitzlein HN: The numbers of nerve fibers in the vagus nerve in man. Anat Rec 1961, 139: 429-435

7. Karnovsky MJ, Roots L: A direct-coloring thiocholine method for cholinesterases. J Histochem Cytochem 1964, 12: 219-221

8. Bell C: Fine structural localization of acetylcholinesterase at a cholinergic vasodilator nerve-arterial smooth muscle synapse. Circ Res 1969, 24: 61-70

9. Nakamura $M$, Oda $M$, Watanabe $N$, Tsukada $N$, Yonei $Y$, Tsuchiya M: Evidence for direct parasympathetic innervation of parietal cells in the rat glandular stomach. Histochemical and electron microscopic cytochemical study. Okajimas Folia Anat Jpn 1982, 59: 167-180

10. Nakamura $M$, Oda $M$, Watanabe $N$, Tsukada $N$, Yonei $Y$, Komatsu $H$, Tsuchiya $M$ : Electron microscopic evidence for cholinergic innervation of the gastric mucosal capillaries in rats: a histochemical, electron microscopic and radioautographic study. In: Courtice FC, Garlick DG, Perry MA, eds, Progress in Microcirculatory Research II, Kensington, Australia, Committee in Postgraduate Medical Education, University of New South Wales, 1984, 284-290

11. Falck B, Hillarp NA, Thieme G, Torp A: Fluorescence of catechol amines and related compounds condensed with formaldehyde. J Histochem Cytochem 1962, 10: 348-354

12. Ajelis V, Bjorklund A, Falck B, Lindvall O, Loren I, Walles B: Application of the aluminum-formaldehyde (ALFA) histofluorescence method for demonstration of peripheral stores of catecholamines and indolamines in freeze-dried paraffinembedded tissue, cryostat sections and whole-mounts. Histochemistry 1979, $65: 1-15$

13. Nakamura $\mathbf{M}$, Watanabe $\mathbf{N}$, Tsukada $\mathbf{N}$, Oda $\mathbf{M}$, Tsuchiya $\mathbf{M}$ : Demonstration of the adrenergic nerves in the rat gastric mucosa: a histofluorescence and electron microscopic study in comparison with the distribution of the cholinergic nerves. Okajimas Folia Anat Jpn 1982, 59: 65-86

14. Valenzuela JE: Dopamine as a possible neurotransmitter in gastric relaxation. Gastroenterology 1976, 71: 1019-1022

15. Nishizaki $Y$, Oda M, Nakamura M, Inoue J, Morishita A. Nishida J, Ishii K, Yokomori M, Kaneko H, Ohya H, Tsuchiya M: Significance of 5-hydroxytryptamine in rat gastric mucosa: immunohistochemical and radioautographic observation. In: Yoshikawa $M$, Uono M, Tanabe H, Ishikawa S, eds, New Trends in Autonomic Nervous System Research, Proceedings of the 20th International Congress of Neurovegetative Research, Amsterdam, Excerpta Medica 1991, 262-263. (International congress series; no 951)

16. Ekblad E, Ekelund M, Graffner $H$, Hakanson R, Sundler F: Peptidecontaining nerve fibers in the stomach wall of rat and mouse. Gastroenterology 1985, 89: 73-85

17. Blitz W, Charbon GA: Regional vascular influences of vasoactive intestinal polypeptide. Scand J Gastroenterol 1983, 18: 755-763

18. Lundberg JM, Hökfelt $T$, Schultzberg M, Üvnas-Wallensten $K$, Köhler C, Said SI: Occurrence of vasoactive intestinal polypeptide (VIP)-like immunoreactivity in certain cholinergic neurons of the cat: evidence from combined immunohistochemistry and acetylcholine esterase staining. Neuroscience 1979, 4: 1539-1559

19. Nakamura $M$, Oda $M$, Kaneko $K$, Akaiwa $Y$, Tsukada $N$, Komatsu $H$, Tsuchiya $M$ : Autoradiographic demonstration of gastrin-rcleasing peptidebinding sites in the rat gastric mucosa. Gastroenterology 1988, 94: 968-976

20. Edwall B, Gazelius B, Fazekas A, Theodorsson-Norheim E, Lundberg JM: Neuropeptide Y (NPY) and sympathetic control of blood flow in oral mucosa and dental pulp in the cat. Acta Physiol Scand 1985, 125: 253-264

21. Holzer P, Livingston EH, Saria A, Guth PH: Sensory neurons mediate protective vasodilatation in rat gastric mucosa. Am J Physiol 1991, 260: G363-G370

22. Forster ER, Dockray GJ: The rolc of calcitonin gene-related peptide in gastric mucosal protection in the rat. Exp Physiol 1991, 76: $623-626$

23. Suematsu M, Suzuki M, Nagata H, Miura S, Houzawa S, Morishita $\mathrm{T}$, Tsuchiya M: Role of neutrophil-mediated oxidative stress in acute gastric mucosal injury induced by microvascular derangement. In: Tsuchiya $M$, Kawai $K$, Kondo $M$, Yoshikawa $T$, eds, Free Radicals in Digestive Diseases. Proceedings of the 1st International Symposium on Free, Radicals in Digestive Diseases, Kyoto, Aug 1987, Amsterdam, Elsevier, 1988, 67-72 (International Congress Series; no 767)

24. Yanagisawa M, Kurihara H, Kimura S, Tomobe $Y$, Kobayashi M, Mitsui Y, Yazaki Y, Goto K, Masaki T: A novel potent vasoconstrictor peptide produced by vascular endothelial cells. Nature 1988, 332: 411-415

25. Palmer RM, Ashton DS, Moncada S: Vascular endothelial cells synthesize nitric oxide from L-arginine. Nature 1988, 333: 664-666

26. Rånby $\mathrm{M}$, Norrman $\mathrm{B}$, Wallen $\mathrm{P}$ : A sensitive assay for tissue plasminogen activator. Thromb Res 1982, 27: 743-749

27. Kurose I, Suematsu M, Miura S, Suzuki M, Nagata H, Morishita $\mathrm{T}$, Sekizuka E, Tsuchiya M: Involvement of superoxide anion and platelet-activating factor in increased tissue-type plasminogen activator during rat gastric microvascular damages. Thromb Res 1991, 62: 241-248

28. Zimmerman GA, McIntyre TM, Mehra M, Prescott SM: Endothelial cell-associated platelet-activating factor: a novel mechanism for signaling intercellular adhesion. J Cell Biol 1990, 110: 529-540

29. Lorant DE, Patel KD, McIntyre TM, McEver RP, Prescott SM, Zimmerman GA: Coexpression of GMP-140 and PAF by endothelium stimulated by histamine or thrombin: a juxtacrine system for adhesion and activation of neutrophils. J Cell Biol 1991, 115: $223-234$

30. Suemastu M, Suzuki M, Nagata H, Miura S, Tsuchiya M: Oxyradicals from leukocytes and degraded nucleic acid derivatives in gastric ulcers induced by microvascular damages. Gastroenterology 1987, 92: 1658

31. Itoh M, Guth PH: Role of oxygen-derived free radicals in hemorrhagic shock-induced gastric lesions in the rat. Gastroenterology 1985, 88: 1162-1167

32. Doenges JL: Spirochetes in gastric glands of Macacus rhesus and humans without definite history of related disease. Proc Soc Exp Biol Med 1938, 38: 536-538

33. Freedberg AS, Barron LE: The presence of spirochetes in human gastric mucosa. Am J Dig Dis 1940, 7: 443-445

34. Palmer ED: Investigation of the gastric mucosa spirochetes of the human. Gastroenterology 1954, 27: 218-220

35. Marshall BJ, Warren JR: Unidentified curved bacilli in the stomach of patients with gastritis and peptic ulceration. Lancet 1984, 1: 1311-1315

36. Goodwin CS: Transfer of Campylobacter pylori and Campylobacter mustelae to Helicobacter gen. nov. and Helicobacter musytelae comb. nov., respectively. Int J Syst Bacteriol 1989. 39: 397-405

37. Dick JD: Helicobacter (Campylobacter) pylori: a new twist to an old disease. Annu Res Microbiol 1990, 44: 249-269

38. Terada S, Yamazaki K, Sakamoto M, Kawanishi K: Distribution 
of Helicobacter pylori in gastric specimens and its mucosal attachment. J Clin Electron Microsc 1991, 24: 536-537

39. Thomsen LL, Gavin JB. Tasman-Jones C: Relation of Helicobacter pylori to the human gastric mucosa in chronic gastritis of the antrum. Gut 1990, 31: 1230-1236

40. Hazell SL, Lee A, Brady L, Hennessy W: Campylobacter pyloridis and gastritis: association with intercellular spaces and adaptation to an environment of mucus as important factors in colonization of the gastric epithelium. J Infect Dis 1986, 153: 658-663

41. Hessey SJ, Spencer J, Wyatt JI, Sobala G, Rathbone BJ, Axon AT, Dixon MF: Bacterial adhesion and disease activity in Helicobacter associated chronic gastritis. Gut 1990, 31: 134-138

42. Wyatt JI, Rathbone BJ, Heatley RV: Local immune response to gastric Campylobacter in non-ulcer dyspepsia. J Clin Pathol 1986, 39: 863-870

43. Karttunen T, Niemela S, Lehtola J, Heikkila J, Maentausta O, Rasanen O: Campylobacter-like organisms and gastritis: histopathology, bilc reflux, and gastric fluid composition. Scand $J$ Gastroenterol 1987, 22: 478-486

4. Hui WM, Lam SK, Chau PY, Ho J, Lui I, Lai CL, Lok AS, $\mathrm{Ng}$ MM: Persistence of Campylobacter pyloridis despite healing of duodenal ulcer and improvement of accompanying duodenitis and gastritis. Dig Dis Sci 1987, 32: 1255-1260

45. Hazell SL, Lee A: Campylobacter pyloridis, urease, hydrogen ion back diffusion, and gastric ulcers. Lancet 1986, 2: 15-17

46. Ramirez-Ramos A, Gilman R, Spira W, Recavarren S, Watanabe J, Leon-Barua R, Rodriguez C, Guevara C, Gago G, Bonilla J, Cok J, Ruiz EH, Gomez E, Olivares E, Garcia R, Klinge GG, Vargas G, Astete M, Valdivia M, Berendson R: Ecology of Helicobacter pylori in Peru: infection rates in coastal, high altitude, and jungle communities. The Gastrointestinal Physiology Working Group of the Cayetano Heredia and the Johns Hopkins University. Gut 1992, 33: 604-605

47. Parsonnet J: The epidemiology of C. pylori. In: Blaser MJ, ed, Campylobacter pylori in Gastritis and Peptic Ulcer Disease, New York, Igaku-Shoin, 1989, 51-60

48. Terada S, Yamazaki K, Kawanishi K: Observation of Helicobactor pylori in the gastric mucosal specimens of patients with chronic gastritis. J Clin Electron Microsc 1990, 23: 622-623

49. Terada S, Fujiwara T, Kawanishi K: Pathogenic changes of gastric tissues of Helicobacter pylori-associated gastritis. J Clin Electron Microse 1992, 25: 460-461
50. Blaser MJ: Epidemiology and pathophysiology of Campylobacter pylori infections. Rev Infect Dis 1990, 12(Suppl 1): S99-S106

51. Hazell SL, Borody TJ, Gal A, Lee A: Campylobacter pyloridis gastritis I: detection of urease as a marker of bacterial colonization and gastritis. Am J Gastroenterol 1987, 82: 292-296

52. Marshall BJ, Warren JR, Francis GJ, Langton SR, Goodwin CS, Blincow ED: Rapid urease test in the management of Campylobacter pyloridis-associated gastritis. Am J Gastroenterol 1987, 82: $200-210$

53. Thillainayagam AV, Arvind AS, Cook RS, Harrison IG, Tabaqchali S, Farthing MJ: Diagnostic efficiency of an ultrarapid endoscopy room test for Helicobacter pylori. Gut 1991, 32: 467-469

54. Evans DJ Jr, Evans DG, Graham DY, Klein PD: A sensitive and specific serologic test for detection of Campylobacter pylori infection. Gastroenterology 1989, 96: 1004-1008

55. Marshall BJ, Surveyor I: Carbon-14urea breath test for the diagnosis of Campylobacter pylori associated gastritis. J Nucl Med 1988, 29: 11-16

56. Klein PD, Graham DY: Detection of Campylobacter pylori by the ${ }^{13} \mathrm{C}$-urea breath test. In: Rathbone $\mathrm{BJ}$, Heatley RV, eds, Campylobacter pylori and Gastroduodenal Disease, Oxford, Blackwell Scientific Publications, 1989, 94-105

57. Rauws EA, Royen EAV, Langenberg W, Woensel JV, Vrij AA, Tytgat GN: ${ }^{14} \mathrm{C}$-urea breath test in C pylori gastritis. Gut 1989 , 30: $798-803$

58. Suzuki M, Miura S, Suematsu M, Fukumura D, Kurose I, Suzuki H, Kai A, Kudoh Y, Ohashi M, Tsuchiya M: Helicobacter pylori-associated ammonia production enhances neutrophildependent gastric mucosal cell injury. Am J Physiol 1992, 263: G719-G725

59. Rauws EA, Tytgat GN: Cure of duodenal ulcer associated with eradication of Helicobacter pylori. Lancet 1990, 335: 1233-1235

60. Weil J, Bell GD, Powell K, Morden A, Harrison G, Gant PW: Omeprazole and Helicobacter pylori: temporary suppression rather than true eradication. Aliment Pharmacol Ther 1991, 5: $309-313$

61. Iwahi T, Satoh H. Nakao M, Iwasaki T, Yamazaki T, Kubo K, Tamura T, Imada A: Lansoprazole, a novel benzimidazole proton pump inhibitor, and its related compounds have selective activity against Helicobacter pylori. Antimicrob Agents Chemother 1991, 35: $490-496$ 